IJOTL -TL, Vol. 2, No. 3, September 2017

p ISSN: 2502 2326; e ISSN: 2502 8278

Http://ijolt1.pusatbahasa.or.id; Email: ijolt1@gmail.com

Center of Language and Cultural Studies, Surakarta, Indonesia

Manshur, Rasyid; Suwandi, Sarwiji \& Suyitno. 2017. Teaching Anecdote Writing Based on

The 2016 Curriculum to the Tenth Graders of SMKN 1 Gondang, Sragen. IJOTL TL (2017), 2(3): 191 202. DOI:10.30957/ijolt1.i2n3.388.

\title{
TEACHING ANECDOTE WRITING BASED ON THE 2016 REVISED CURRICULUM TO THE TENTH GRADERS OF SMKN 1 GONDANG SRAGEN
}

\author{
Rasyid Manshur, Sarwiji Suwandi \& Suyitno \\ Graduate Program of Indonesian Language Education \\ Sebelas Maret University \\ Jl. Ir. Sutami 36 A Kentingan Surakarta, Central Java, Indonesia \\ Corresponding author: rasyidmanshur14@yahoo.com
}

\begin{abstract}
This study describes: (1) process of writing anecdote text based on the 2016 revised curriculum conducted by Indonesian Language teachers to the tenth graders of SMKN 1 Gondang, Sragen, (2) problems in the process of writing, and 3) efforts to overcome the problems made by the teachers. This qualitative research uses case study approach. The data sources in this research were events (the process of writing anecdote text), informants (teachers and students), and documents (syllabus and lesson plan). The results show that teaching to write anecdote text based on the 2016 revised curriculum needs more in-depth evaluation in order to improve planning, implementation, and assessment. It is also based on the encountered obstacles occurred in the learning process. The evaluation should uncover concepts, regulations and national education objectives implied in the curriculum the schools should attain.
\end{abstract}

Keywords: 2013 curriculum, revised 2016 curriculum, writing, anecdote text.

DOI:10.30957/ijolt1.i2n3.388.

\section{INTRODUCTION}

Curriculum is often identified with teaching materials or textbooks. According to Sanjaya (2008:3) the term curriculum was first used in sports in the ancient Greek period derived from the word curir and curere. People called it a place to race from start to finish. Furthermore the term curriculum is used in education. Experts have different interpretations, there are similarities. The similarity is that the curriculum is closely linked to the efforts of developing learners in line with the goals to be achieved.

Education in Indonesia has been regulated in Law Number 202003 regarding the National Education System (SISDIKNAS). It is stated about the function and purpose of national education is to develop the ability and form the character and civilization of dignified nation in order to educate the life of the nation, aiming at the development of 
IJOTL TL, Vol. 2, No. 3, September 2017

p ISSN: 2502 2326; e-ISSN: 2502 8278

Http://ijolt1.pusatbahasa.or.id; Email: ijolt1@gmail.com

Center of Language and Cultural Studies, Surakarta, Indonesia

Manshur, Rasyid; Suwandi, Sarwiji \& Suyitno. 2017. Teaching Anecdote Writing Based on

The 2016 Curriculum to the Tenth Graders of SMKN 1 Gondang, Sragen. IJOTL TL (2017), 2(3): 191 202. DOI:10.30957/ijolt1.i2n3.388.

the potential of learners to become a believer and be conscious of God, knowledgeable, creative, independent, and a democratic and responsible citizen.

To achieve the function and purpose of national education is needed a tool. Idi (2007:51) mentions the tools to achieve that educational goal is a curriculum. The curriculum has an important role in the process of organizing national education. Meanwhile, Oliva (1997:12) mentions the definition of the curriculum as "Curriculum is a construct or concept, a verbalization of an extremely complex idea or set of ideas." Similarity is also expressed by Arifin (2012:22) considered very strategic and vital because the curriculum will direct all educational activities, including facilities and infrastructure as well as those involved in it to achieve educational goals. The curriculum position can also be seen from the educational system itself. Education as a system certainly has various components that are interconnected and interdependent. The components of the education, among others, are education goals, education curricula, learners, environment, facilities and infrastructure, management, and technology. These components can be accomplished through the teaching process.

The 2013 curriculum is a curriculum designed to prepare learners in the face of their future challenges. The government through education and cultural ministers feels it is necessary to prepare more curriculum than the previous. One of the reasons of the 2013 Curriculum need is the future demands and future competencies. The future challenges, namely the demands of globalization, the advancement of information technology, the knowledge-based economy as well as the shifting world economic power that must be taken into account in the development of the curriculum. While the demand for future competence is very different from the demands of skills in the 20th century. These skills are communication, problem-solving, innovative and creative ability and mastering information technology. In addition, ethical, social, political and legal issues in the global world are of vital importance. Therefore, the 2013 Curriculum is a part of preparing Indonesian human beings to have the ability to live as a productive, creative, innovative and effective citizen and citizen and capable of contributing to the life of society, nation, state and world civilization.

The 2016 revised curriculum is a renewal and improvement of the previous 2013 curriculum. Renewal is done to add less to the applied education system. Content or curriculum content of the 2013 revision of 2016 written in Ministry of Education and Culture decree Number 24 Year 2016 on Basic Competency and Basic Competence of Lessons in the 2013 Curriculum on Basic Education and Secondary Education, the competence is expressed in the form of Core Competencies (KI) which are categorically illustrated on inner competence aspects of attitude, knowledge, and skills (cognitive and psychomotor) that learners should learn for a school level, class and subject. Then, KI is further elaborated in the Basic Competency (KD) which is the competency learned by the learners for a theme for SD / MI, and for subjects in certain classes for SMP / MTS, SMA / MA, SMK / MAK.

The Indonesian language learning in the 2013 revision of the 2016 Curriculum is still the same as the 2013 curriculum that applies text-based learning based on the principle: language is seen as text, linguistic selection to express meaning, functional 
IJOTL TL, Vol. 2, No. 3, September 2017

p ISSN: 2502 2326; e-ISSN: 2502 8278

Http://ijolt1.pusatbahasa.or.id; Email: ijolt1@gmail.com

Center of Language and Cultural Studies, Surakarta, Indonesia

Manshur, Rasyid; Suwandi, Sarwiji \& Suyitno. 2017. Teaching Anecdote Writing Based on

The 2016 Curriculum to the Tenth Graders of SMKN 1 Gondang, Sragen. IJOTL TL (2017), 2(3): 191 202. DOI:10.30957/ijolt1.i2n3.388.

language, and language is a means of forming thinking ability. Indonesian is seen as a vehicle to express thoughts, both verbally and in writing.

Learning Indonesian is basically directed to master four language skills, namely listening, reading, speaking, and writing. Writing is to lower or depict the graphical symbols that describe a language that a person understands, so that others can read the symbols of the graph if they understand the language and graphic representation (Tarigan, 2013:22). In line with that opinion, Andayani (2015:191) says writing is to lower or depict the symbols of the graph that illustrate a language that one understands so that others can read the symbols of the graph directly if they understand the language and the graphic. So, writing is a language skill after listening, speaking, and reading skills that is a productive creative process to bring down or depict the symbols of a written language for a particular purpose.

The main purpose of writing writers is as a means of communication indirectly. Authors and readers can communicate through writing. This is based on the principle of writing is to convey the author's message to the reader, so that the reader understands the intent or intentions expressed through the writing (Kusumaningsih, et al., 2013:67). In the communication process the authors convey ideas, feelings, and experiences to readers. Therefore, writing learning cannot be done instantly. Writing activities are the language skills most difficult to master by students. Then, the only way to teach writing is through writing exercises.

Indonesian Language Learning in the 2013 Curriculum does not directly specify the division of language skills as in KTSP. However, in any textual material there is a basic competence to produce texts, one of which is based on the 2013 revision of the 2016 curriculum syllabus enacted in the Ministry of Education and Culture decree No. 22 of 2016 on the Basic and Secondary Education Process Standard one of which is the anecdote text for the $\mathrm{X}$ grade level SMA/ SMK/ MA. Anecdote text is a text that describes interesting, interesting stories that are hilarious and impressive in their form of critique or satire on policy, public service, rogue behavior, or a phenomenon or event (Priyatni, 2014:92-93).

Priyatni (2014:93) expresses how the specifics of the anecdote text structure are: 1) The title, the anecdote text title is usually short, solid, directly referring to the object/ object in anecdotes; 2) Abstract, anecdote text is included in narrative text category (story). Typically, the anecdote text starts with an abstract that contains a brief description of the object or the thing to be slandered or criticized; 3) Orientation, story continued with the introduction of perpetrators and events; 4) Crisis, loading event and story stages begins to peak and is almost heading to completion; 5) Reactions, answers to problems posed in the crisis. This is the essence of criticism that contains funny / impressive elements and is the essence of the curiosity/ criticism; 6) The cod, contains the cover, which is an affirmation of what is criticized/ denied.

Problems in writing learning are still dominant than other language skills. Some students point out that in writing, they have difficulty expressing ideas in writing but they have many ideas. The problem requires a description of the writing learning process at school. The sustainability of learning has always been influenced by a variety 
IJOTL TL, Vol. 2, No. 3, September 2017

p ISSN: 2502 2326; e-ISSN: 2502 8278

Http://ijolt1.pusatbahasa.or.id; Email: ijolt1@gmail.com

Center of Language and Cultural Studies, Surakarta, Indonesia

Manshur, Rasyid; Suwandi, Sarwiji \& Suyitno. 2017. Teaching Anecdote Writing Based on

The 2016 Curriculum to the Tenth Graders of SMKN 1 Gondang, Sragen. IJOTL TL (2017), 2(3): 191 202. DOI:10.30957/ijolt1.i2n3.388.

of factors, such as learning implementation plans, teaching materials, learning methods, learning media, learners' conditions, and educators themselves. Selective teaching materials, methods, and media will only cause learning problems. The selection of the components should consider things like the needs of learners, interests, and learning environments. The lecture method by the teacher is indeed a student need in learning, but it does not always have to be done continuously, considering that the student in the 2013 revision of the 2016 Curriculum is an active learning subject. Therefore, teachers are expected to be able to design interesting, creative, and active learning so students' learning is not passive.

Implementation of the 2013 revision of the recently implemented 2016 Curriculum is still subject to obstacles in planning, implementation, and assessment that affect the implementation of the curriculum. These three components are an integral, interdependent, and interdependent entity. Constraints arise from sources of learners, educators, or other external constraints such as facilities and infrastructure, learning resources, learning time, and so forth. Thus, the role of strategy is needed to overcome these constraints.

The learning of Indonesian language especially in the writing of anecdote texts in SMK Negeri 1 Gondang Sragen regency can be observed as the implementation process of the 2013 revision of the 2016 Curriculum and to know whether it is in accordance with the ideal criteria of the 2013 curriculum revision 2016. SMK Negeri 1 Gondang Sragen Regency has become one of schools that run the 2013 revised 2016 Curriculum in the 2016/2017 school year. This study examines starting from learning planning, implementation of learning, to assessment and evaluation of learning. In addition, this study also examines the constraints or problems encountered during the process of writing anecdote texts along with the efforts to address these problems.

\section{METHODS}

This study was conducted at SMK Negeri 1 Gondang Sragen Regency by taking a customized study time of the 2016/2017 curriculum semester program. This study is a qualitative research with a single, single case study approach. Arifin (2012:168) mentions that case studies are a comprehensive and comprehensive study of learners, classes or schools that have specific cases. The sources of data in this study are the events of writing anecdotes texts, informants namely teachers and students, as well as documents such as syllabus and RPP. Technique of sampling of this research is purposive sampling. Meanwhile, data collection techniques used are observation, interview, document analysis, and questionnaire. Test data validity using data triangulation, method triangulation, and informant review. While, the data analysis technique used is an interactive model of analysis with the following steps: data collection, data reduction, data presentation, and conclusion drawing.

\section{FINDINGS AND DISCUSSION}

The curriculum reform dynamics 2013 is certainly underpinned by the many strong reasons that the government has examined in order to give birth, the 2013 
IJOTL TL, Vol. 2, No. 3, September 2017

p ISSN: 2502 2326; e-ISSN: 2502 8278

Http://ijolt1.pusatbahasa.or.id; Email: ijolt1@.gmail.com

Center of Language and Cultural Studies, Surakarta, Indonesia

Manshur, Rasyid; Suwandi, Sarwiji \& Suyitno. 2017. Teaching Anecdote Writing Based on

The 2016 Curriculum to the Tenth Graders of SMKN 1 Gondang, Sragen. IJOTL TL (2017), 2(3): 191 202. DOI:10.30957/ijolt1.i2n3.388.

revision of the 2016 Curriculum, which is the concept of change that provides fresh air for curriculum and education improvement in Indonesia. Problems both in the implementation of KTSP and the 2013 Curriculum have been reviewed as curriculum evaluation materials. The 2013 revision of the 2016 curriculum was developed to cope with a wide range of future problems and challenges that are increasingly complex and the volume of complexity is increasingly dense. 2013 revision curriculum 2016 is expected to provide positive feedback for learners to be qualified generation successors through proportional balances on the competence of attitudes, knowledge and skills.

The results of the study conducted by Law (2010) conclude the existence of specific conditions in the development of school-based curriculum. Furthermore, the development of the school curriculum in China is the responsibility of teachers and schools, in fact the participation of teachers is hampered by the leadership style and the position of leaders involved in the development team. This is relevant to the development of the 2013 Curriculum that is oriented to the future of learners because of their lives in the hands of educators.

Educators or teachers and learners or students are the main character in a learning process drama on the 2013 revision of the 2016 Curriculum. The learning process is performed by two leaders in each other consisting of the lesson planning prepared by the teacher, then the implementation performed by both as well as assessments or evaluations by teachers, not forgetting the students are able to provide feedback. To monitor the achievement or the learning outcomes that have been done. As mentioned above, then the main task of teachers in the 2013 revision of the 2016 Curriculum should be implemented by every teacher for the implementation of the 2013 revision of the 2016 Curriculum that is in line with the regulations set by the government.

\subsection{Learning Process}

There are three main stages in the implementation of the curriculum namely the planning stage, the implementation stage, and the evaluation phase. First, the planning stage is the benchmark and the guidelines in the implementation of learning. Although this stage of planning is still referred to as a planned early stage in the form of RPP, however, its arrangement should be kept in detail, among others in the selection of basic competencies, teaching materials, learning media, learning methods, learning resources, and assessment methods RPP itself as a planning document which will later be followed up in the implementation of learning.

RPPs owned by Indonesian language teachers at SMK Negeri 1 Gondang Sragen Regency were developed together with the Teacher Training Faculty (MGMP) Indonesian SMK in Sragen Regency. RPP formulation is developed based on syllabus that has been prepared by the government and its guide.

The analysis of the RPP documents compiled by Indonesian teachers at SMK Negeri 1 Gondang Sragen regency shows that most of the drafting of RPP has followed the rules contained in Ministry of Education and Culture decree No. 22 of 2016 on the Basic and Secondary Education Process Standard. However, the incompatibility of the formulation of the description in the RPP is also still found, in the formulation of 
IJOTL TL, Vol. 2, No. 3, September 2017

p ISSN: 2502 2326; e-ISSN: 2502 8278

Http://ijolt1.pusatbahasa.or.id; Email: ijolt1@gmail.com

Center of Language and Cultural Studies, Surakarta, Indonesia

Manshur, Rasyid; Suwandi, Sarwiji \& Suyitno. 2017. Teaching Anecdote Writing Based on

The 2016 Curriculum to the Tenth Graders of SMKN 1 Gondang, Sragen. IJOTL TL (2017), 2(3): 191 202. DOI:10.30957/ijolt1.i2n3.388.

teaching materials, learning media, and learning resources that are considered to have not considered a particular aspect. In addition, incompatibilities in the systematic and RPP formats, such as the existence of the substance of learning methods in RPP are also found. The substance of the learning method should not stand alone, but it is integrated into the steps of learning activities. Labane (2009:5) revealed, "Curriculum implementation plans are required to assist the implementers to obtain a common understanding of the required curriculum practice. These plans become devices for identifying ways of solving or minimizing problems related to implementation ". In its implementation, each curriculum, in particular the new curriculum will face many problems. Planning Phase will help identify ways to address the problem and help reduce the problems that will arise in the implementation of the curriculum.

Second, the implementation stage covers preliminary, core, and cover activities. The three are a series of interrelated learning steps in determining the course of learning. Ministry of Education and Culture decree Number 222016 About the Basic and Secondary Education Process Standards has set the order of implementation of the three stages of the activity.

Preliminary activities as the first activity were carried out by Indonesian teachers at SMK Negeri 1 Gondang Sragen, among them by saying greetings, asking questions, asking the attendance of students in terms of quantity, linking the material previously learned with the material to be delivered by the teacher, asking about the difficulties or the student's understanding of the previous material, expressing the benefits of learning, and demonstrating the learning material associated with factual issues in economic, social and political fields. Before stepping on the subject matter, the teacher points out the competencies to be achieved. In addition, the delivery of an outline of activities is also carried out by the teacher in the study along with the culmination and confusion of the material to be learned. The data can be a red thread indicating that most of the preliminary activities have been done well according to the concept and provisions of Ministry of Education and Culture decree Number 22 Year 2016.

The next activity is the core activity as the second activity. The core activities of the 2013 revision of the 2016 curriculum are learning using learning models, learning methods, learning media, and learning resources tailored to the characteristics of learners and subjects. The selection of learning approaches is tailored to the characteristics of competence and education level. In the teaching of anecdotal teacher of Indonesian in SMK Negeri 1 Gondang Sragen Regency applies a scientific approach which includes five phases, namely: asking, observing, collecting information, associating, and communicating.

Description of the core activity stages in learning to write anecdote texts as follows: 1) In the observation stage, the teacher directs the learners to read and understand the intrinsic elements and examples of anecdote texts in the student's book; 2) In the questionnaire phase, the teacher gives the widest opportunity to learners to ask, but no one asks; 3 ) In the stage of collecting information, the teacher directs the learners to collect information based on the topics to be raised in anecdote text writing; 4) At the level of associating data the teacher has provided the worksheet Learners write the data 
IJOTL -TL, Vol. 2, No. 3, September 2017

p ISSN: 2502 2326; e ISSN: 2502 8278

Http://ijolt1.pusatbahasa.or.id; Email: ijolt1@gmail.com

Center of Language and Cultural Studies, Surakarta, Indonesia

Manshur, Rasyid; Suwandi, Sarwiji \& Suyitno. 2017. Teaching Anecdote Writing Based on

The 2016 Curriculum to the Tenth Graders of SMKN 1 Gondang, Sragen. IJOTL TL (2017), 2(3): 191 202. DOI:10.30957/ijolt1.i2n3.388.

that has been collected in the worksheet then proceeded by starting to compose anecdote text according to the intrinsic element; 5) In the communicative phase, learners are given the opportunity to present the results of their writing and the teacher also gives other learners the opportunity to respond to the anecdote texts that the student has presented. In the closing phase of the 2013 revision of the 2016 Curriculum, as well as groups reflecting to evaluate: 1) all series of learning activities and results obtained to further collectively find out the benefits directly or indirectly from the learning outcomes that have taken place; 2) provide feedback on learning processes and outcomes; 3) conducting follow-up activities in the form of assignment, both individual and group assignments; and 4) inform the lesson plan for the next meeting. In an enclosed learning activity the teacher delivers criticism and suggestions on the student's work and instructs improvements to students who are not in line with the elements in the writing of anecdote texts.

\subsection{Assessment}

At this assessment stage, Indonesian language teachers at SMK Negeri 1 Gondang Sragen regency have conducted assessments in accordance with the indicators and instruments that have been specified in RPP. The preparation of assessment instruments has been completed with assessment guidelines. As the final stage in learning, evaluations are evaluated in order to measure the basic competencies of learners along with the indicators that have been implemented in the learning process. In the teaching of anecdote text writing, teachers are using a portfolio evaluation technique to assess the anecdote textual product produced by the learners both individually and in groups according to the indicators of achievement of competence. Guidelines for scoring anecdote text skills have been supplemented with assessed aspects, scores, and assessment criteria. So, the teacher is able to determine the sustainability of the learning that he has done.

Based on the results of the study, it can be seen that the implementation of the teaching of anecdonal text in the X grade of SMK Negeri 1 Gondang Sragen regency as a whole has been in line with what was planned. However, there are some component findings whose implementation is incompatible with what has been planned in the RPP, namely the utilization of learning resources, learning media, and synthesized learning models. This can be an evaluation of improvements to the implementation of learning in the 2013 revision of the 2016 Curriculum so that the course of learning is successful and materialized as expected.

\subsection{Problems and Solution to Solve the Learning Process}

Various constraints in the learning process in the 2013 revision of the 2016 curriculum become a distinct work challenge for educators. Problems or constraints especially in the teaching of anecdote text writing can be seen either from the planning stage, the implementation stage, or the assessment stage. The following are the problems faced by teachers at the planning stage, such as the adjustment of the format and systematics of RPP and the determination of time allocation. Implementation phase 
IJOTL TL, Vol. 2, No. 3, September 2017

p ISSN: 2502 2326; e-ISSN: 2502 8278

Http://ijolt1.pusatbahasa.or.id; Email: ijolt1@gmail.com

Center of Language and Cultural Studies, Surakarta, Indonesia

Manshur, Rasyid; Suwandi, Sarwiji \& Suyitno. 2017. Teaching Anecdote Writing Based on

The 2016 Curriculum to the Tenth Graders of SMKN 1 Gondang, Sragen. IJOTL TL (2017), 2(3): 191 202. DOI:10.30957/ijolt1.i2n3.388.

is also not out of the name of the problem, the constraints faced by teachers are the determination of learning methods and time allocations applied to core activities. In addition, the constraints on the assessment stage that teachers find is a detailed assessment complexity so that teachers are obliged to process quantities that are quantities so much that it takes a long time to say.

Constraints not only come from teachers, learners also become the trigger of problems. Problems of learners are influenced by internal and external factors. The internal factor itself is the concentration of the student, the interest, and the understanding. Meanwhile, external factors are on the development of paragraphs and the proper language use. Class and school environments, learning resources, learning time, and the support of infrastructure facilities lack of inherent obstacles of the control of teachers and learners. This is in line with the results of Bennie and Newstead's research (1999:4) stating that the obstacles to the implementation of the new curriculum, mainly related to the lack of substance of the curriculum content that imply implications for implementation, teacher's inadequacy, student's abilities, and school culture. Thus, these problems need to be addressed by a variety of strategies so that the curriculum implementation process can be done in accordance with the established rules. The red thread is to minimize the inequalities between curriculum concepts set with the form of implementation in the field.

Various strategies have been taken as a form of effort to overcome obstacles and to optimize the process of writing text anecdotes in the implementation of the 2016 revision of the 2016 curriculum. In this regard, the role of teachers is as facilitator and occupy an important position in the management of learning materials because almost entirely in teachers (Mulyasa, 2014:193). Teacher's efforts are as follows. At the planning stage, RPPs should be maximized by educators formulating the Ministry of Education and Culture decree Number 22 of 2016 on the Basic and Secondary Education Process Standard. This is because the syllabus has been prepared by the government, both in the national curriculum and in the regional curriculum so that teachers live to develop a less intuitive learning plan (Mulyasa, 2014:181). On the other hand, in terms of allocation of time allocation, teachers must be able to cope with considering aspects of effective day number, number of KDs, and depth of teaching materials so that time allocations are planned to be appropriate.

In addressing the problem of the method, the teacher's effort is to sort and choose the appropriate method in learning Indonesian language by adjusting the characteristics of learners. In addition, the teacher is obliged to create a center of excellence the role of learners in order for the creativity of the learners to be more optimal in order to produce anecdote texts. In applying the allocation of learning time to core activities, teachers can strive for learning that does not raise the overall learning experience in just one meeting, but can be followed up at the next stage of the meeting with no dependence on the scope of the teaching material.

At the assessment stage, teachers can overcome problems with the effort to explore the study and learn more detail on the guidelines that have been mentioned in Decision Number 23 Year 2016 on Education Evaluation Standards. Authentic 
IJOTL TL, Vol. 2, No. 3, September 2017

p ISSN: 2502 2326; e-ISSN: 2502 8278

Http://ijolt1.pusatbahasa.or.id; Email: ijolt1@gmail.com

Center of Language and Cultural Studies, Surakarta, Indonesia

Manshur, Rasyid; Suwandi, Sarwiji \& Suyitno. 2017. Teaching Anecdote Writing Based on

The 2016 Curriculum to the Tenth Graders of SMKN 1 Gondang, Sragen. IJOTL TL (2017), 2(3): 191 202. DOI:10.30957/ijolt1.i2n3.388.

assessments have a holistic and intimate nature that includes affective or attitudinal, cognitive or knowledge, psychomotor or skills aspects. This authentic assessment will have implications for the assessment process teachers are doing based on the criterion guidelines. Constraints in the learning process that come from learners are influenced by internal factors and external factors. Constraints sourced from internal factors are concentration of learners, understanding, and interests. Meanwhile, the constraints that are derived from the external factors of the learners are the development of paragraphs and the use of the standard language.

The other constraints are constraints that come from outside the control of educators and learners such as classroom environment, school environment, learning resources, learning time, and learning facilities and infrastructures. Based on these internal factors, the teacher's efforts to overcome the obstacles encountered by the learners during the learning process take place as follows. Regarding the concentration of learning concentrations, the teacher undertakes a strategy by providing a centralized direction for learners to focus more on learning, selecting and utilizing the right method, creating engaging learning by utilizing learning media, and conducive classroom management. Regarding the constraints of understanding, teachers explain personal explanations to learners who do not understand, giving learners the opportunity to ask, effective two-way communication between teachers and learners, as well as integrating teaching materials that are closely related to real-life learners. Regarding the growing interest of learners towards learning, the effort that teachers do is to motivate learners intensely by not diminishing the view of the background of learners.

Growing interest in learners is also sought by teachers through interesting and fun learning so learners are motivated and interested in learning. Based on these external factors, the teacher's efforts are to overcome the constraints of the development of the paragraph, which is to remind the material about the anecdotal structure and the types the paragraph corresponding to the main sentence. Teachers also point out and explain back to the previous lesson about making chart charts as a strategy for developing paragraphs. In terms of the constraints of the use of raw language, teachers use a pilot strategy or provide examples to learners, as well as conditioned learners to get used to oral or written writing that always use good and correct Indonesian language.

Meanwhile, efforts to overcome obstacles beyond the control of teachers and learners like a learning environment that is utilizing the environment as a learning resource. Whereas, in dealing with constraints of learning resources, teachers use a strategy in the form of instruction to learners about which sources of learning can be referred to as an educational material support for anecdote text writing. About time constraints of learning addressed the teacher through the adjustment of students' conditions during daytime or late afternoon learning by creating more intense learning to attract their attention. Additionally, day-to-day or late afternoon learning can be well done by the learners if the teacher does not give a heavy task to the learners. Finally, facilities and learning resources that are still obstacles to these facilities and infrastructures are not just the responsibility of the government to provide them, but it is also the responsibility of the school community to continue to improvise, initiate, create, 
IJOTL -TL, Vol. 2, No. 3, September 2017

p ISSN: 2502 2326; e-ISSN: 2502 8278

Http://ijolt1.pusatbahasa.or.id; Email: ijolt1@gmail.com

Center of Language and Cultural Studies, Surakarta, Indonesia

Manshur, Rasyid; Suwandi, Sarwiji \& Suyitno. 2017. Teaching Anecdote Writing Based on

The 2016 Curriculum to the Tenth Graders of SMKN 1 Gondang, Sragen. IJOTL TL (2017), 2(3): 191 202. DOI:10.30957/ijolt1.i2n3.388.

and innovate in order to address the limitations of facilities and infrastructure, so the 2016 revision of the 2016 Curriculum can work well.

\section{CONCLUSION}

The learning process of writing anecdote texts includes three phases, namely the planning, implementation, and closing stages. The conclusions that can be drawn based on findings, analyzes and discussions are the formats and systematics of RPP formulated by teachers at SMK Negeri 1 Gondang Sragen regency have been in line with the principle of formulation of RPP contained in Ministry of Education and Culture decree No. 22 of 2016 on the Basic Education Process Standard and Medium. However, nonconformities such as the determination of learning resources, the media, and their learning methods are still found.

Implementation stages in learning process of writing anecdote text have been well done. However, some of the components in the implementation are not in accordance with the planned RPP, such as the utilization of learning resources, media and learning tools, as well as the applied learning models are still found. The closing phase is that the teacher gives an assessment of the attitudes during the course of the study, while for the assessment of the results the teacher is carried out through the evaluation of the product or portfolio that the students have done.

Constraints or problems during the learning process are sourced from teachers, participants, and external factors from both. Constraints from teachers include the suitability of the format and systematics of the RPP formulation, the chosen learning method, the allocation of time divided, and the complexity of the assessment which should also be detailed. Problems of learners include learning interest, concentration, understanding, paragraph development, and the use of standard language. Constraints outside the control of teachers and learners include classroom and school environments, learning resources, learning time, and facilities and infrastructure. As an effort to ensure the continuity of the 2016 Curriculum implementation of the 2016 revision can run optimally in every aspect, various strategies need to be implemented. Therefore, the role of the teacher is able to perform various strategies with all the competencies they have to overcome the problems encountered during the learning process.

The results of the data analysis on the implementation of the 2016 Curriculum 2013 revision on the anecdotes textual study show that deeper assessment is still indispensable so as to provide improved implementation improvements ranging from planning, implementation, and evaluation. This is due to the fact that obstacles in the implementation of the 2013 revision of the 2016 Curriculum have become more and more dynamic in the education world following the development of the era, so the implementation of the 2013 revised 2016 curriculum in line with the concepts and regulations set by the government can be realized, also implies the achievement of national educational goals. 
IJOTL TL, Vol. 2, No. 3, September 2017

p ISSN: 2502 2326; e ISSN: 2502 8278

Http://ijolt1.pusatbahasa.or.id; Email: ijolt1@gmail.com

Center of Language and Cultural Studies, Surakarta, Indonesia

Manshur, Rasyid; Suwandi, Sarwiji \& Suyitno. 2017. Teaching Anecdote Writing Based on The 2016 Curriculum to the Tenth Graders of SMKN 1 Gondang, Sragen. IJOTL TL (2017), 2(3): 191 202. DOI:10.30957/ijolt1.i2n3.388.

\section{REFERENCES}

Andayani. (2015). Problema dan Aksioma dalam Metodologi Pembelajaran Bahasa Indonesia. Yogyakarta: Penerbit Deepublish.

Arifin, Z. (2012). Konsep dan Model Pengembangan Kurikulum. Bandung: Remaja Rosdakarya.

Bennie, Kate and Karen Newstead. (1999). Obstacles to Implementation a New Curriculum. www.academic.sun.ac.za. Diakses 21 Juni 2017.

Idi, Abdullah. (2007). Pengembangan Kurikulum: Teori dan Praktik. Jogjakarta: ArRuzz Media.

Kusumaningsih, dkk. (2013). Terampil Berbahasa Indonesia. Yogyakarta: Penerbit ANDI.

Labane, Nokubonga. (2009). Planning and Managing Curriculum Implementation in Rural Schools: an Investigation, Nelson Mandela Metropolitan University, www.- dspace.nmmu.ac.za:8080. Diakses 21 Juni 2017.

Law, Edmon H.F; Wan, Sally W.Y; Galton, Maurice; Lee, John C.K. (2010). Managing school-based curriculum innovations: a Hong Kong case study. Curriculum Journal. Volume 21, Issue 3, 2010. http:// www.tandf.co.uk/journals/titles. (Online 15 Juni 2017)

Mulyasa. (2014). Pengembangan dan Implementasi Kurikulum 2013. Bandung: PT Remaja Rosdakarya.

Oliva, Peter F. (1997). Developing The Curriculum (Third edition). Harper Collins Publishers: United States

Peraturan Menteri Pendidikan dan Kebudayaan Nomor 22 Tahun 2016 tentang Standar Proses Pendidikan Dasar dan Menengah.

Peraturan Menteri Pendidikan dan Kebudayaan Nomor 23 Tahun 2016 tentang Standar Penilaian Pendidikan.

Peraturan Menteri Pendidikan dan Kebudayaan Nomor 24 Tahun 2016 tentang Kompetensi Dasar Pelajaran Pada Kurikulum 2013 Pada Pendidikan Dasar dan Menengah.

Priyatni, E.T. (2014). Desain Pembelajaran Bahasa Indonesia dalam Kurikulum 2013. Jakarta: PT. Bumi Aksara.

Tarigan, H. G. (2013). Menulis sebagai Suatu Keterampilan Berbahasa. Bandung: Penerbit Angkasa. 
IJOTL TL, Vol. 2, No. 3, September 2017

p ISSN: 2502 2326; e-ISSN: 2502 8278

Http://ijoltl.pusatbahasa.or.id; Email: ijolt1@gmail.com

Center of Language and Cultural Studies, Surakarta, Indonesia

Manshur, Rasyid; Suwandi, Sarwiji \& Suyitno. 2017. Teaching Anecdote Writing Based on The 2016 Curriculum to the Tenth Graders of SMKN 1 Gondang, Sragen. IJOTL TL (2017), 2(3): 191 202. DOI:10.30957/ijolt1.i2n3.388.

Sanjaya, Wina. (2008). Kurikulum dan Pembelajaran: Teori dan Praktik Pengembangan Kurikulum Tingkat Satuan Pendidikan (KTSP). Jakarta: Fajar Interpratama Offset.

Undang-Undang Nomor 20 Tahun 2003 tentang Sistem Pendidikan Nasional. 